EETP Vol. 15, 2020, №. 2(56)

ISSN 1896-2327 / e-ISSN 2353-7787

DOI: $10.35765 /$ eetp.2020.1556.06

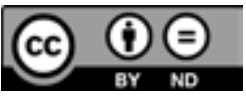

Nadesłano: 23.03.2020

Zaakceptowano: 11.05 .2020

Sugerowane cytowanie: Pufund D. (2020). Story-based intervention. Historyjki społeczne jako metoda pracy z uczniem ze spektrum autyzmu, "Edukacja Elementarna w Teorii i Praktyce", vol. 15, nr 2(56), s. 77-94. DOl: 10.35765/eetp.2020.1556.06

\title{
Story-based intervention. Historyjki społeczne jako metoda pracy z uczniem ze spektrum autyzmu
}

\author{
Story-Based Intervention. Social Stories as a Method \\ of Working with a Student with the Autism Spectrum
}

\footnotetext{
SŁOWA KLUCZE ABSTRAKT

autystyczne Podążając wzorem innych dyscyplin naukowych, także i pedagogika spektrum zaburzeń, stoi przed wyzwaniem wdrażania modelu pracy w oparciu o badania historyjki społeczne, naukowe an evidence-based. Przedmiotem badania jest przegląd i anasamoregulacja, liza wyników raportów z badań nad skutecznością interwencji z wyspecjalne potrzeby korzystaniem social stories wobec uczniów z zaburzeniami ze spektrum edukacyjne autyzmu na etapie edukacji elementarnej. Głównym celem analizy jest popularyzacja social stories jako skutecznej metody pracy z uczniem z zaburzeniami ze spektrum autyzmu. Przegląd literatury objął zagraniczne periodyki naukowe, dostępne za pośrednictwem baz elektronicznych. Wyłonione w kwerendzie materiały zostały poddane analizie szczegółowej, zwłaszcza pod kątem przedmiotu badań, celów oraz przebiegu interwencji z wykorzystaniem historyjki społecznej. Wyłoniono wskazania w zakresie stosowania historyjek społecznych w pracy z dzieckiem z zaburzeniami ze spektrum autyzmu. Mając na względzie obiektywne ograniczenia zaprezentowanych raportów z badań, nasuwa się refleksja nad koniecznością kontynuowania badań nad ich skutecznością.
} 


\section{KEYWORDS ABSTRACT}

autistic spectrum

disorder, social

stories, self-

regulation, special

educational needs
Following the example of other scientific disciplines, pedagogy faces the challenge of implementing an evidence-based work model. The subject of the research is the review and analysis of the results of reports concerning the effectiveness of implementing social stories in working with the students with autism spectrum disorders at the elementary education stage. The main goal of the study is to popularize social stories as an effective method of working with such students. The reviewed literature encompassed foreign scientific journals available via electronic databases. The materials selected in the query were thoroughly analysed, particularly in terms of the subject of research, its goals and the course of an intervention with the use of a social story. Indications for the application of social stories while working with a child with the autism spectrum were identified. Taking into account the objective limitations of the presented research reports, there appears to be the need to continue the research on the effectiveness of story-based interventions.

\section{Wprowadzenie}

Iwona Chrzanowska za jedną z istotnych barier w procesie wdrażania edukacji inkluzyjnej (łac. includere - włączenie, dołączenie, zawieranie) jako ,,modelu idealnego systemu szkolnego", wskazuje konieczność zmiany myślenia w zakresie tzw. kultury organizacyjnej szkoły (Chrzanowska 2018; 2019). Zgodnie z danymi zawartymi w Systemie Informacji Oświatowej (w roku szkolnym 2018/2019, stan na 30.09.2018) odnotowano w placówkach następujący rozkład liczebności uczniów z diagnozą autyzmu, w tym zespołu Aspergera: w przedszkolach kształcenie specjalne realizuje 12077 dzieci (w tym w przedszkolach specjalnych 2093 dzieci) oraz w szkołach podstawowych 21422 uczniów (w tym w szkołach specjalnych 1514 uczniów). Analiza danych statystycznych wymusza wręcz konieczność przyspieszenia przeobrażeń w obszarze „kultury organizacyjnej” placówek oświatowych. Nie jest to jednak możliwe bez usunięcia barier w postaci mylnego rozumienia bądź fragmentarycznej wiedzy na temat specyfiki funkcjonowania edukacyjnego uczniów z niepełnosprawnością oraz o neuroróżnorodnej ścieżce rozwoju. Stwierdzenie to nie jest bynajmniej odosobnione. Postulat konieczności zmian jest niezwykle ważnym głosem środowiska (m.in. na III Międzynarodowej konferencji „Autyzm. Światłocienie” zorganizowanej przez Fundację Prodeste w 2019 r. w Toruniu), wobec którego pedagodzy i pedagożki nie moga pozostawać obojętnymi. Wśród najczęstszych zarzutów wobec podejmowanych aktualnie najpowszechniej strategii terapeutycznych wymienić można chociażby: odejście od solidnych podstaw naukowych stosowanych metod; niski poziom responsywności 
terapeutów; literalne, bezrefleksyjne podążanie za metodą; koncentrowanie na modyfikowaniu zachowania, nie zaś na zaspokajaniu potrzeb; nadmierną - niekiedy też wręcz ambiwalentną czy dyskusyjną w zakresie swojej zasadności, dyrektywność. Żadna metoda nie stanowi magicznego panaceum na autyzm. Nie istnieje metoda terapii autyzmu - wszak autyzm nie jest chorobą (sic.). Terapii sensu stricto podlegają trudności w konkretnych obszarach funkcjonowania, i tak dla zaburzeń ze spektrum autyzmu osiowe trudności dotyczą sfery społeczno-emocjonalnej, komunikacji oraz percepcji sensorycznej (DSM-5 2018).

W artykule dla ujednolicenia posługuję się terminem z ab u r ze n i a ze spek$\mathrm{t} \mathrm{ru} \mathrm{m}$ a u t y z m u, bez precyzyjnego różnicowania funkcjonowania uczniów na tych z diagnozą autyzmu oraz zespołem Aspergera. Uzasadnieniem przyjęcia takiej perspektywy jest opublikowana w 2013 roku Klasyfikacja Zaburzeń Psychicznych Amerykańskiego Towarzystwa Psychiatrycznego DSM-5, która przynosi zmiany w zakresie definiowania autyzmu. W porównaniu z wcześniejszym wydaniem oraz klasyfikacją ICD-10, w DSM-5 zastąpiono trzy całościowe zaburzenia rozwojowe: autyzm, zespół Aspergera oraz całościowe zaburzenia rozwojowe niezdiagnozowane inaczej wspólną kategorią nadrzędną - zaburzeń ze spektrum autyzmu (z ang. autism spectrum disorders - ASD). Ponadto z klasyfikacji wyłączono zespół Retta i dziecięce zaburzenia dezintegracyjne (Morrison 2016).

Podążając wzorem innych dyscyplin naukowych, także i pedagogika stoi przed wyzwaniem wdrażania modelu pracy w oparciu o badania naukowe. Zgodnie z raportem National Autism Center opublikowanym w 2015 roku, wśród ustanowionych naukowo interwencji wobec dzieci, adolescentów oraz dorosłych z zaburzeniami ze spektrum autyzmu poniżej 22. r.ż. wyróżnić można: interwencje behawioralne oparte na założeniach stosowanej analizy zachowania (ang. Behavioral Interventions), kognitywną terapię behawioralną (ang. Cognitive Behavioral Intervention Package), trening językowy (ang. Language Training), modelowanie (ang. Modeling), naturalne strategie uczenia (ang. Natural Teaching Strategies), trening rodzicielski (ang. Parent Training), trening rówieśniczy (ang. Peer Training Package), trening kluczowej odpowiedzi/reakcji (ang. Pivotal Response Training), plany aktywności (ang. Schedules), skrypty (ang. Scripting), trening samozarządzania (ang. Self-Management), trening umiejętności społecznych (ang. Social Skills Package) oraz interwencje opierające się na opowieściach społecznych (ang. Story-based Intervention) (NAC 2015; Suchowierska, Novak 2013). Jak zauważają Sam Goldstein i Sally Ozonoff, niski poziom funkcjonowania społecznego stanowi istotny czynnik, często przesądzający o diagnozie autyzmu (Goldstein, Ozonoff 2017). Dokonując przeglądu dostępnych form doskonalenia zawodowego oraz kwalifikacji nauczycieli i terapeutów-specjalistów w zakresie pomocy psychologiczno-pedagogicznej, nie można oprzeć się wrażeniu, iż największą popularnością cieszą się te w zakresie terapii behawioralnej. Istotnie zarysowuje się także 
dysproporcja pomiędzy opracowaniami naukowymi na temat interwencji behawioralnych wobec osób z zaburzeniami ze spektrum autyzmu a doniesieniami odnoszącymi się do pozostałych metod uznanych za an evidence-based. Wiadomości na ich temat można znaleźć w przeważającej większości w literaturze zagranicznej, co znacznie utrudnia ich implementację do praktyki edukacyjnej i terapeutycznej.

Przedmiotem badania jest przegląd i analiza wyników raportów z badań nad skutecznością interwencji - rozumianą jako stopień, w jakim osiągnięte są zamierzone cele (Kondalkar 2010 za: Pyszka 2015) z wykorzystaniem social stories wobec uczniów z zaburzeniami ze spektrum autyzmu na etapie edukacji elementarnej. Głównym celem badania jest popularyzacja social stories jako skutecznej metody pracy z uczniem z zaburzeniami ze spektrum autyzmu. Artykuł otwiera omówienie założeń teoretycznych metody social stories oraz zasady konstruowania historyjki społecznej według koncepcji Carol Gray. W oparciu o przegląd literatury omówiono możliwości wykorzystania historyjek społecznych wobec uczniów z zaburzeniami ze spektrum autyzmu na poziomie wczesnej edukacji, a także sformułowano wskazania w zakresie stosowania historyjek społecznych w praktyce pedagogicznej.

\section{Social Stories według Carol Gray - założenia teorełyczne metody}

Historyjki społeczne (z ang. social stories) to zindywidualizowane, krótkie historyjki opisujące określoną sytuację społeczną - przekonania, stany emocjonalne oraz skrypty behawioralne z perspektywy jej odbiorcy, za pomocą odpowiedniej organizacji formalno-językowej (Gray, Garand 1993; Gray 1998; Pisula 2012; Atwood 2013; Gray 2014; Prokopiak 2017). Fenomenu popularności metody na świecie upatrywać można w silnym jej zakorzenieniu w praktyce szkolnej. Carol Gray, autorka i propagatorka metody, w latach 1977-2004 pracowała jako nauczycielka dzieci i młodzieży z zaburzeniami ze spektrum autyzmu w Jenison Public Schools in Jenison, Michigan. Pierwsze historyjki społeczne powstały w 1989 roku w odpowiedzi na potrzeby jej wychowanków oraz próby poradzenia sobie z ich trudnościami (https://carolgraysocialstories.com).

Teoretycznego uzasadnienia zastosowania historyjek społecznych wobec uczniów z zaburzeniami ze spektrum autyzmu Gray upatruje w tzw. deficytach poznawczych, które wpływają na ich trudności w zakresie rozumienia społecznego (Gray, Garand 1993). Ujęcie Gray bliskie jest tzw. poznawczym koncepcjom autyzmu: deficytu teorii umysłu - zdolności do identyfikowania, rozpoznawania, rozumienia myśli, intencji, pragnień innych osób, dzięki czemu możliwe jest rozumienie i przewidywanie ich zachowań (Baron-Cohen 1995, za: Atwood 2013) oraz słabej centralnej 
koherencji - skłonności do myślenia fragmentarycznego, trudności z zakresie różnicowania informacji, łączenia ich w spójną całość (Firth, Happé 1994; Atwood 2013).

Jednym z podstawowych założeń interwencji w oparciu o historyjkę społeczną jest dialog oraz podmiotowe traktowanie odbiorcy, poprzez dążenie do zrozumienia indywidualnej, subiektywnej percepcji zdarzeń. W historyce społecznej zakłada się występowanie sprzężenia zwrotnego pomiędzy odbiorcą, który ma trudności ze zrozumieniem oczekiwanego wzorca zachowania społecznego, a profesjonalistami, rodzicami, opiekunami, w końcu także rodzeństwem. Gray wyodrębniła 10 zasad konstruowania historyjki społecznej, które mają wpływ na skuteczność podejmowanej z jej zastosowaniem interwencji (Tabela 1.).

Tabela 1. Zasady konstruowania historyjki społecznej według koncepcji Carol Gray

\begin{tabular}{|c|c|c|}
\hline \multicolumn{2}{|c|}{ Kryterium wg Carol Gray } & Omówienie \\
\hline \multicolumn{2}{|l|}{ Jeden cel } & $\begin{array}{l}\text { Celem historyjki społecznej jest dzielenie się informacjami z od- } \\
\text { biorcą w możliwe jasny i przejrzysty sposób, biorąc pod uwagę jego } \\
\text { równowagę psychiczną, fizyczną, społeczną i emocjonalną. } \\
\text { Celem historyjki społecznej jest wyposażenie odbiorcy w wiedzę, } \\
\text { nie zaś modyfikowanie jego zachowania. }\end{array}$ \\
\hline \multicolumn{2}{|l|}{ Dwa kroki } & $\begin{array}{l}\text { Praca nad tworzeniem historyjki obejmuje dwa etapy: zbieranie } \\
\text { precyzyjnych danych; określenie sytuacji z indywidualnej perspek- } \\
\text { tywy odbiorcy historyjki. } \\
\text { Gray wyróżniła trzy rodzaje informacji zawarte w historyjkach } \\
\text { społecznych: wiadomości - informacje obiektywne; interpretacje } \\
\text { wiadomości - informacje opisujące; oraz powiązania i konsekwen- } \\
\text { cje - informacje wiążące przeszłość, teraźniejszość i przyszłość. }\end{array}$ \\
\hline \multicolumn{2}{|c|}{ Trzy części i tytut } & $\begin{array}{l}\text { Historyjka ma trójdzielną kompozycję: wstęp, rozwinięcie } \\
\text { i zakończenie-podkreślenie. }\end{array}$ \\
\hline \multicolumn{2}{|l|}{ Format } & $\begin{array}{l}\text { Istotny jest sposób prezentacji i organizacji historyjki, tak by od- } \\
\text { powiadała ona na indywidualne potrzeby odbiorcy, a więc dbałość } \\
\text { o jej odpowiednią długość, dobór słownictwa oraz kompozycję } \\
\text { gramatyczną tekstu, stylu czcionki, wielkości oraz koloru, a także } \\
\text { umieszczenie zdjęć, symboli oraz ilustracji. }\end{array}$ \\
\hline \multirow[t]{2}{*}{ Pięć aspektów } & perspektywa & \multirow{2}{*}{$\begin{array}{l}\text { Pisząc historyjkę społeczną, należy zwrócić uwagę na: perspektywę } \\
\text { pierwszo- lub trzecioosobową, dbałość o cierpliwy ton odpowiedzi, } \\
\text { stosowanie czasu przeszłego i teraźniejszego i/lub przyszłego, precy- } \\
\text { zyjność i dosłowność wypowiedzi, odpowiedni dobór słownictwa. }\end{array}$} \\
\hline & stownictwo & \\
\hline \multicolumn{2}{|c|}{ Sześć pytań w historyjce } & $\begin{array}{l}\text { Mając na względzie precyzję wypowiedzi, historyjka powinna za- } \\
\text { wierać odpowiedzi na następujące pytania: kto? co? kiedy? gdzie? jak? } \\
\text { oraz dlaczego? }\end{array}$ \\
\hline
\end{tabular}




\begin{tabular}{|c|c|}
\hline Siedem rodzajów sformutowań & $\begin{array}{l}\text { W historyjce dopuszcza się stosowanie następujących rodzajów } \\
\text { sformułowań: } \\
\text { - } \quad \text { opisowe: stwierdzenia obiektywne o sytuacji; } \\
\text { opiniujące: stwierdzenia dotyczące stanu człowieka } \\
\text { (np. jego myśli, uczuć, poglądów); } \\
\text { szkoleniowe: stwierdzenia dotyczące zalecanej reakcji, za- } \\
\text { chowania się (mogą odnosić się do odbiorców, do zespołu } \\
\text { lub mieć charakter samodoskonalący); } \\
\text { utwierdzające: stwierdzenia podkreślające, wzmacniające } \\
\text { wcześniej przekazaną informację; } \\
\text { niepełne: stwierdzenia z lukami do uzupełnienia. }\end{array}$ \\
\hline Przepis na sukces & $\begin{array}{l}\text { Istotą treści historyjki społecznej jest opis sytuacji, nie zaś wydawa- } \\
\text { nie poleceń oraz zaleceń ukierunkowanych na zmianę zachowania. } \\
\text { Gray zaleca pracę nad treścią historyjki, zachowując odpowiednie } \\
\text { jej rozplanowanie, tj. utrzymanie proporcji między liczbą zdań opi- } \\
\text { sujących a liczbą zdań uczących (ich iloczyn powinien być większy } \\
\text { lub równy 2). }\end{array}$ \\
\hline Po swojemu & $\begin{array}{l}\text { Historyjka społeczna ma uwzględniać indywidualne preferencje, } \\
\text { zainteresowania potrzeby i ograniczenia odbiorcy. }\end{array}$ \\
\hline $\begin{array}{l}\text { Dziesięć wskazówek dotycza- } \\
\text { cych redakcji i wdrażania }\end{array}$ & $\begin{array}{l}\text { Gray zaleca przestrzeganie następujących zasad: klarowności i przy- } \\
\text { stępności tekstu, gotowości do korzystania z pomocy np. oprogra- } \\
\text { mowania oraz aplikacji, odpowiednią organizację pracy z historyj- } \\
\text { ką-sposobu i częstotliwości interwencji, monitorowanie postępów } \\
\text { pracy oraz dokonywanie jej ewaluacji, a także porządkowanie hi- } \\
\text { storyjek z uwagi na ich treść, stopnień trudności oraz tematykę. }\end{array}$ \\
\hline
\end{tabular}

Źródło: opracowanie własne (Gray, Garand 1993: 1-10; Gray 1998: 167-198; Gray 2014).

\section{Badania własne}

Badanie zaprojektowano zgodnie z metodyką przeglądu literatury, przeprowadzono je w pięciu fazach: wyszukiwania wstępnego, wyszukiwania pełnego i pozyskiwania literatury, ekstrakcji i oceny zebranych dowodów, syntezy i analizy wyników oraz raportowania (Czakon 2011; Booth 2012, za: Mazur, Orłowska 2018). Na etapie przygotowawczym wyłoniono podstawową literaturę przedmiotu z zagranicznych periodyków naukowych, dostępnych za pośrednictwem baz elektronicznych (DOAJ). $\mathrm{Na}$ drugim etapie - wyszukiwania pełnego i pozyskiwania literatury, dokonano jej selekcji. Posłużono się strategią wyszukiwania i selekcji prac za pomocą procedury tzw. słów kluczy. Zastosowano następujące słowa kluczowe: interwencja w oparciu o opowieści (ang. story-based intervention), historyjki społeczne (ang. social stories), 
zaburzenia ze spektrum autyzmu (ang. autism spectrum disorder). Posłużono się także kryterium eliminacji artykułów, mając na względzie cezurę czasową - analizie podległy prace po 2000 roku, oraz wieku uczestników - tj. uczniów wczesnej edukacji. Analiza wstępna literatury obejmowała przegląd abstraktów. Następnie dokonano stratyfikacji artykułów, wyodrębniono te bezpośrednio dotyczące podejmowanego zagadnienia możliwości wykorzystania social stories $\mathrm{w}$ pracy z uczniem z zaburzeniami ze spektrum autyzmu w środowisku szkolnym oraz adekwatne do celów badania. Pozwoliło to na ekstrakcję danych - 22 artykułów do analizy treściowej. Wyłonione w kwerendzie materiały zostały poddane analizie szczegółowej; interesował mnie w szczególności przedmiot badań, cele oraz przebieg interwencji z wykorzystaniem historyjki społecznej. W raporcie przedstawiono efekt skończonego projektu badawczego.

\section{Wykorzystanie historyjek społecznych wobec dzieci z zaburzeniami ze spektrum autyzmu w świetle badań}

Na podstawie przeglądu literatury możliwe jest wyodrębnienie dwóch głównych obszarów problemowych w kontekście zastosowania interwencji w oparciu o historyjki społeczne. Na poziomie behawioralnym są to doniesienia dotyczące poprawy funkcjonowania dziecka w zespole klasowo-lekcyjnym, zmniejszenie intensyfikacji zachowań zakłócających i problemowych. Druga grupa interwencji koncentruje się na funkcjonowaniu społeczno-emocjonalnym oraz komunikacyjnym, tj. możliwościach wspomagania zachowań prospołecznych, doskonalenia umiejętności kluczowych w zakresie interakcji społecznych oraz samodzielnej zabawy u dzieci z zaburzeniami ze spektrum autyzmu.

\section{Regulowanie reakcji behawioralnych}

Pierwszą grupę badań otwierają doniesienia dotyczące poprawy funkcjonowania uczniów w zespole klasowo-lekcyjnym po zastosowaniu interwencji z wykorzystaniem historyjek społecznych. Zespół Jeffreya Chana oraz Marka O’Reilly’ego objął badaniem grupę trzech 8-letnich uczniów z diagnozą autyzmu, uczęszczających do szkoły ogólnodostępnej - co, jak podkreślają autorzy, jest szczególnie istotne, biorąc pod uwagę przeważającą liczbę badań w odniesieniu do uczniów placówek specjalnych. Nauczyciele-eksperymentatorzy za pomocą programu Microsoft PowerPoint stworzyli historyjki społeczne, dostosowując ich treści oraz formę do indywidualnych potrzeb uczniów oraz ich poziomu funkcjonowania. Każda z historyjek obejmowała do 12 slajdów - pojedynczy slajd zawierał krótką (ograniczoną do maksymalnie 4 zdań) wypowiedź, zapisaną czcionką bezszeryfową o wielkości 20 pkt, oraz przedstawienia 
wizualnego w formie zdjęcia, rysunku bądź fotografii. Uczniowie uczestniczyli w sesjach terapeutycznych z użyciem indywidualnie przygotowanej historyjki społecznej przed rozpoczęciem właściwych zajęć lekcyjnych. Dla każdego z chłopców zoperacjonalizowano indywidualne cele terapeutyczne, takie jak: odpowiednie siedzenie, nawiązywanie kontaktu wzrokowego z nauczycielem oraz poprawa samodzielności w pisaniu i czytaniu w trakcie zajęć. Badacze odnotowali umiarkowane zmiany w zachowaniu dzieci, jednak miały one nieharmonijny przebieg (Chan, O’Reilly i in. 2011).

Podobne wyniki dostarczyły badania irańskie, przeprowadzone przez zespół Uniwersytetu w Teheranie (Beh-Pajooh i in. 2011). Uczestnikami badania było troje uczniów szkoły specjalnej w wieku 8-9 lat. U dwojga z nich zauważono spadek zachowań zakłócających, takich jak płacz (w wymiarze 86\%), nieuzasadnionego chodzenia po klasie $(93 \%)$ oraz pokładania się na ławce $(83 \%)$. Podobny rezultat w zakresie ograniczenia płaczu u dzieci z zaburzeniami ze spektrum autyzmu objętych interwencją opartą o historyjki społeczne uzyskali również inni badacze (Agosta i in. 2004; Adams, Gouvousis 2004). Badacze Richmond Mancil, Todd Haydon oraz Peggy Whitby odnotowali nieznacznie większą efektywność zastosowanej interwencji wobec uczniów z autyzmem w oparciu o historyjki społeczne wykonane za pomocą programu PowerPoint niż w zastosowaniu tradycyjnej wersji papierowej (Mancil, Haydon, Whitby 2009).

Skuteczność stosowania interwencji w oparciu o historyjki społeczne potwierdzono także w badaniu tajlandzkim przeprowadzonym przez Angkhana Khantreejitranon (Khantreejitranon 2018). Do 6-tygodniowego eksperymentu włączono grupę pięciorga dzieci z diagnozą autyzmu w wieku 6-10 lat. Jako kryterium doboru uczestników w badanu zastosowano stopień nasilenia trudności w zakresie umiejętności społecznych. Wyodrębniono następujące kluczowe obszary będące przedmiotem interwencji: chodzenie w kółko, wydawanie głośnych dźwięków, trudności z dzieleniem się zabawkami z innymi dziećmi, trudności z regulacją emocjonalną (m.in. okazywanie frustracji niewspółmiernie do sytuacji), trudności z regulacją behawioralną (m.in. niszczenie zabawek), trudności z płynnym przechodzeniem z jednej aktywności w drugą, trudności z inicjowaniem i podtrzymywaniem interakcji w sposób akceptowany społecznie. Interwencja obejmowała pięć 30-minutowych spotkań z dziećmi. Do interwencji posłużono się klasycznymi historyjkami społecznymi według zaleceń Gray oraz zastosowano indywidualnie dobraną historię społeczną dla każdego dziecka w formie e-booka. Do ewaluacji posłużono się ankietą skierowaną do nauczycieli uczniów oraz Intervention Rating Profile. Badacze odnotowali spadek intensyfikacji zachowań trudnych i zakłócających w badanych obszarach.

Skuteczność metody odnotowali także Shannon Crozier oraz Matt Tincani. W badaniu wzięło udział troje dzieci w wieku od 3-5 lat z diagnozą autyzmu, uczęszczających do przedszkola uniwersyteckiego, w którym realizowano model edukacji włączającej. Każda z faz badania miała miejsce w sali lekcyjnej uczestników. Historyjki 
obejmowały następujące cele behawioralne: siedzenie w czasie zajęć w kole, utrzymywanie spokojnych rąk i nóg w czasie siedzenia przy stole oraz zachowania w trakcie przekąski/ posiłku. Książeczki zawierały prostą ilustrację (np. rysunek precla) oraz jednozdaniowy podpis na stronie zapisany 14-punktową czcionką w stylu Time New Roman. U wszystkich uczestników odnotowano poprawę zachowania w obszarach, w których podjęto interwencję, jednakże po jej ukończeniu nie utrzymywała się ona w czasie w zadowalającym stopniu (Crozier, Tincani 2007). Z kolei badacze Uniwersytetu w Teksasie potwierdzili utrzymywanie się pozytywnych zachowań do 10 miesięcy po przeprowadzeniu interwencji z wykorzystaniem historyjek społecznych u dwojga uczniów 5 i 6-letnich z diagnozą autyzmu (Chan, O’Reilly 2008).

W literaturze pojawiają się także doniesienia na temat skuteczności indywidualnych interwencji zastosowanych wobec uczniów z zaburzeniami ze spektrum autyzmu. Christine Norris oraz John Datillo zastosowali zindywidualizowane historyjki społeczne wobec 8-letniej dziewczynki z autyzmem. Interwencja odbywała się codziennie, przez 10 minut, na około kwadrans przed udaniem się do szkolnej stołówki poza klasą dziecka. Odnotowano redukcję o 50\% zachowań zakłócających w trakcie lunchu (hałasowania, śpiewania) w odniesieniu do liczby zachowań w trakcie pierwszego dnia interwencji. Niestety nie uwzględniono pomiaru, który sugerowałby utrzymywanie się zmiany zachowań w czasie (Norris, Dattilo 1999). Wyniki zastosowanej indywidualnej interwencji przedstawił także zespół badawczy Ellen Agosty, Janet E. Graetz, Margo A. Mastropieri oraz Thomasa E. Scruggsa. Terapią objęto 6-letniego chłopca z diagnozą autyzmu. Posłużono się dwiema zindywidualizowanymi historyjkami społecznymi zgodnie z zaleceniami Gray. Do jej utworzenia wsparto się oprogramowaniem BoardMaker. W czasie systematycznej interwencji chłopiec pracował indywidualnie z nauczycielką w oparciu o historyjki społeczne podnoszące kwestie zachowań takich jak: krzyk, płacz, głośne nucenie podczas aktywności w grupie rówieśniczej zajęć w kręgu. Mimo zaprzestania interwencji, wykonane badanie kontrolne pozwoliło odnotować utrzymanie się spadku zachowań zakłócających w postaci krzyku oraz wydłużonego uczestniczenia dziecka w zajęciach zorganizowanych w kręgu, co pozwala prognozować pozytywny skutek podjętych oddziaływań (Agosta, Graetz i in. 2004).

Raport Lynn Adams, Aphroditi Gouvousis, Michaela VanLue oraz Claire Waldron potwierdza efektywność wsparcia rodziców w redukowaniu poziomu frustracji oraz poprawę gotowości do wysiłku umysłowego podczas odrabiania pracy domowej dzięki zastosowaniu historyjki społecznej. Interwencję przeprowadzono w domu 7-letniego chłopca z diagnozą autyzmu. Obejmowała ona łącznie 48 sesji. Stworzona dla ucznia historyjka społeczna odbiegała od zaleceń Gray, gdyż interwencja skierowana była na cztery zachowania: krzyk, płacz, upadanie na ziemię oraz uderzanie rękoma. Zachowania zostały wybrane w oparciu o przeprowadzoną wcześniej funkcjonalną ocenę zachowania we współpracy z rodzicami i nauczycielami ucznia. Zastosowana 
interwencja pozwoliła na zmniejszenie częstotliwości występowania zachowań niepożądanych, jednak nie doprowadziła do ich całkowitego wyeliminowania (Adams, Gouvousis i in. 2004).

\section{Regulowanie reakcji emocjonalnych oraz rozwijanie kompetencji społeczno-komunikacyjnych}

Badania przeprowadzone przez Naomi Schneider oraz Howarda Goldsteina wskazują na wysoki poziom efektywność interwencji w oparciu o historyjki społeczne, zastosowanej wobec dzieci z zaburzeniami ze spektrum autyzmu (Schneider, Goldstein 2009). Do badania włączono troje uczniów wczesnej edukacji (dwoje 6-letnich, jedno 9-letnie), którzy wykazywali wzmożone nasilenie zachowań trudnych oraz korzystali z systematycznej terapii logopedycznej z uwagi na zaburzenia komunikowania się i mowy. Rozwój języka oraz komunikacji dzieci został oceniony za pomocą The Social Skills Rating System oraz The Oral and Written Language Scales. Uczniowie pracowali z historyjką społeczną poza salą lekcyjną w czasie systematycznych, indywidualnych sesji z nauczycielem, zaś obserwacja ich zachowań odbywała się podczas zajęć z grupą rówieśniczą. Wybór zachowań poddawanych interwencji poprzedzała konsultacja z nauczycielami, logopedą, a także, co szczególnie istotne dla ciągłości interwencji z rodzicami dziecka. Każde z nich powiązane było z indywidualnym planem edukacyjno-terapeutycznym. Badacze zwrócili również uwagę na niemożność uwzględnienia niektórych zachowań dzieci w obszarze interwencji, np. echolalii. Każda historyjka społeczna była indywidualnie przygotowywana do potrzeb i możliwości dziecka w formie laminowanych kart oprawionych w segregator. Karty przygotowano z zastosowaniem 20-punktowej czcionki Times New Roman oraz symboli PCS (ang. The Picture Communication Symbols) wygenerowanych za pomocą programu BoardMaker. U uczniów zaobserwowano wzrost pozytywnych zachowań, jednak ich rozkład był nieharmonijny i indywidualny dla każdego z uczestników. W kolejnym badaniu Schneider i Goldstein odnotowali wzrost efektywności interwencji z wykorzystaniem historyjek społecznych wobec uczniów z zaburzeniami ze spektrum autyzmu w wyniku zastosowania strategii wspomagającej w formie wizualnych planów aktywności oraz tablic - ang. visual schedules (Schneider i Goldstein 2010).

Badanie Susany Bernad-Ripoll dotyczyło oceny skuteczności interwencji w oparciu o historyjki społeczne oraz filmy wideo z udziałem uczestnika. Interwencją objęto 9-letniego ucznia z zespołem Aspergera. W celu zdobycia materiałów do tworzenia indywidualnych historyjek społecznych dziecko było nagrywane i fotografowane w różnych sytuacjach, tak by możliwe było zwizualizowanie szerokiego wachlarza doświadczanych przez nie stanów emocjonalnych oraz wielokrotne powracanie do nich. 
Przedmiotem interwencji był wzrost kompetencji społeczno-emocjonalnych w zakresie identyfikowania, rozpoznawania oraz rozumienia emocji: szczęścia, gniewu, niepokoju, spokoju, a także frustracji. Sesje terapeutyczne z dzieckiem odbywały się w domu, podczas jednej sesji pracowano nad jedną historyjką społeczną (łącznie odbyło się 9 sesji). Na podstawie zebranych danych odnotowano wzrost poprawnych odpowiedzi ucznia w zakresie określania emocji, jednak ich liczba miała tendencję spadkową (Bernad-Ripoll 2007).

Osobną grupę stanowią badania podejmujące kwestię funkcjonowania na poziomie społeczno-emocjonalnym, tj. wspomagania zachowań prospołecznych, doskonalenia umiejętności kluczowych w zakresie interakcji społecznych oraz samodzielnej zabawy. Badaczki Leasha M. Barry oraz Suzanne B. Burlew skoncentrowały się na ocenie możliwości wykorzystania interwencji w oparciu o historyjki społeczne w rozwijaniu umiejętności dokonywania wyboru aktywności, adekwatnego użycia przedmiotów oraz zabawy uczniów z autyzmem. W badaniu uczestniczyli 7- i 8-letni uczniowie z diagnozą autyzmu o niskich kompetencjach językowych. Obserwacja uczniów odbywała się 3 razy w tygodniu przez 30 minut. Praca z historyjkami społecznymi odbywała się codziennie w czasie trwania fazy interwencyjnej, a także podczas zajęć w grupie rówieśniczej, w czasie których nauczyciel udzielał uczniom korygujących informacji zwrotnych w oparciu o historyjkę. Badaczki odnotowały poprawę zachowań w obszarach objętych interwencją (Barry, Burlew 2004).

Badanie przeprowadzone przez Tiffany L. Hutchins oraz Patricię A. Prelock z Uniwersytetu Vermont potwierdza skuteczność interwencji z zastosowaniem historyjek społecznych oraz historyjek komiksowych (ang. Comic Strip Conversations - CSC) jako strategii wspierającej wzrost pozytywnych zachowań prospołecznych uczniów z zaburzeniami ze spektrum autyzmu. W badaniu uczestniczyło siedemnaścioro dzieci w wieku 4-12 lat z diagnozą medyczną autyzmu oraz wiekiem rozwoju w zakresie ekspresji werbalnej plasującym się na poziomie minimum trzeciego roku życia. Do każdej indywidualnie przygotowanej historyjki dołączano fotografie oraz symbole wygenerowane za pomocą programu BoardMaker. Do pomiaru skuteczności oddziaływań badaczki zastosowały następujące narzędzia badawcze: The Gilliam Autism Rating Scale - GARS, The Clinical Evaluation of Language Fundamentals-Observational Rating Scales - CELF-ORS oraz Social Skills Rating Scale - SSRS. Analiza zebranego materiału wskazała, iż podejmowane oddziaływania były skuteczne aż w 76,5\% (Hutchins, Prelock 2012).

Z kolei celem badania Lisy Wright oraz Rebecci McCathren była ocena inicjowania kontaktów rówieśniczych oraz pozytywnych reakcji na inicjację kontaktów przez rówieśników u dzieci z zaburzeniami ze spektrum autyzmu (Wright, McCathren 2012). Do oceny poziomu funkcjonowania społecznego wykorzystano The Social Responsiveness Scale oraz The Carolina Curriculum for Infants and Toddlers with Special Needs. 
W badaniu uczestniczyło czterech chłopców w wieku 3-7 lat z diagnozą autyzmu. Jako kryterium wykluczenia zastosowano brak istotnych opóźnień w rozwoju poznawczym oraz prezentowanie podstawowych umiejętności językowych i komunikacyjnych. Dzieci pracowały z dwiema indywidualnie opracowanymi historyjkami społecznymi. Każda z nich miała postać zalaminowanej, kilkustronicowej książeczki (5-11 stron), zapisanej 16-punktową czcionką w stylu Times New Roman. Książki zawierały zdjęcia dzieci oraz ich rówieśników. Historyjki były czytane dzieciom co najmniej raz dziennie, o tej samej porze w trakcie indywidualnej sesji z nauczycielem. Badaczki odnotowały nieznaczny wzrost zachowań prospołecznych u trzech chłopców oraz nieznaczny spadek zachowań zakłócających. Kolejne badanie potwierdziło zwiększenie liczby zachowań prospołecznych u uczniów z autyzmem wobec ich rówieśników po zastosowaniu interwencji z użyciem historyjki społecznej. W badaniu uczestniczyło trzech chłopców z diagnozą autyzmu w wieku 8-13 lat, komunikujących się werbalnie z otoczeniem. Dla każdego z uczniów przygotowano indywidualną historię społeczną, w formacie zalaminowanych kart oprawionych w segregator. Każda ze stron zawierała jedno lub dwa zdania zapisane czcionką 14-punktową. Na podstawie analizy zebranych danych ustalono progres w zakresie interakcji społecznych, z następującym rozkładem dla poszczególnych uczestników: 39\% - 13-latek, 28\% - 8-latek oraz 4\% - 8-latek, co sugeruje możliwość wzrostu motywacji do podejmowania interakcji społecznych wraz z wiekiem uczniów (Scattone, Tingstrom, Wilczynski 2006).

W badaniu malezyjskim uczestniczyło czworo dzieci w wieku od 5-8 lat z diagnozą zaburzeń ze spektrum autyzmu, uczących się w szkolnictwie integracyjnym po rekomendacji udzielonej przez nauczycieli. Projekt trwał 5 tygodni, obejmował: codzienną pracę dziecka z dostosowaną do potrzeb i możliwości dziecka historyjką społeczną oraz obserwację zachowań dzieci w zespole klasowo-lekcyjnym oraz w czasie przerw, m.in. w trakcie ich swobodnej aktywności na boisku. Na podstawie przeprowadzonej interwencji z zastosowaniem historyjek społecznych odnotowano poprawę u trojga uczestników badania w zakresie podejmowania interakcji z rówieśnikami oraz dzielenia pola uwagi. W przypadku jednego z dzieci nie zaobserwowano zmian w jakości i liczbie podejmowanych interakcji rówieśniczych. Badacze zwrócili również uwagę na istotny warunek skuteczności pracy w oparciu o historyjki społeczne, jakim jest dbałość o ciaggłość oddziaływań terapeutycznych w środowisku domowym, m.in. poprzez włączenie w oddziaływania rodziców dzieci za pośrednictwem wcześniej przygotowanych materiałów, np. w formie komiksów, myślowych chmurek, a także aplikacji mobilnych przeznaczonych do tworzenia krótkich animacji: Tellagami, prezentacji i materiałów audiowizualnych - Book Creator oraz poświęconych temu stron internetowych, takich jak Voki. Zwrócono także uwagę na konieczność powtarzania historyjki społecznej z dziećmi w odpowiednich do ich potrzeb interwałach czasowych (Balakrishnan, Alias 2017). Zasadność włączania urządzeń mobilnych bądź komputerowo wspomaganych 
instrukcji (ang. Computer-Assisted Instruction - CAI) do interwencji z wykorzystaniem historyjek społecznych potwierdzają także raporty innych badaczy (Hagiwara, Smith 1999; Cihak, Kildare i in. 2012; Edeiken-Cooperman 2014; Stathopoulou, Loukeris i in. 2020 ).

\section{Zakończenie}

Obok doniesień na temat skuteczności interwencji z zastosowaniem opowieści społecznych, pojawia się także refleksja dotycząca jej niskiej skuteczności. Zauważono, iż interwencja w oparciu o historyjki społeczne wpływa jedynie na niektórych uczniów z zaburzeniami ze spektrum autyzmu, zaś u pozostałych uczestników interwencji zaobserwowano znikome zmiany w wymiarze komunikacyjnym, nie odnotowano oczekiwanej poprawy na poziomie behawioralnym (Graetz 2003; Sansosti, Powell-Smith 2006; Watts 2008). Na trudności w jednoznacznej ocenie skuteczności terapii dzieci z zaburzeniami ze spektrum autyzmu w oparciu o historyjki społeczne wpływają ograniczenia w zakresie możliwości wyabstrahowania konkretnych zmiennych istotnych dla zmiany zachowania, jednoczesne stosowanie innych oddziaływań terapeutycznych - np. SAZ, tj. stosowanej analizy zachowania (Kuoch, Mirenda 2003; Marr, Mika i in. 2007), a także, w przeważającej większości, mała liczba dzieci objętych interwencją oraz jej krótkotrwałe skutki.

Analiza literatury pozwala wnioskować, iż wyniki badań dotyczące skuteczności interwencji z zastosowaniem historyjek społecznych nie są jednoznaczne i rozstrzygające. Mimo tego, historyjki społeczne należy uznać za istotne narzędzie pracy indywidualnej z dzieckiem z zaburzeniami ze spektrum autyzmu. W oparciu o kwerendę literatury wyłonić można wskazania w zakresie stosowania historyjek społecznych w praktyce pedagogicznej na trzech poziomach:

1. Planowanie pracy z historyjką społeczną:

- z uwagi na zindywidualizowany charakter opowieści społecznych uznać można za zasadne jej stosowanie na poziomie pracy indywidualnej (lub, jeśli nie jest to możliwe $\mathrm{z}$ uwagi na strukturę organizacyjną przedszkola i szkoły, w małej grupie, tj. diadzie, triadzie terapeutycznej, wówczas dobór do grupy poprzedzać powinna szczegółowa analiza obszarów wymagających wsparcia - grupy powinny być możliwe jednorodne pod względem doświadczanych trudności oraz prezentowanych możliwości poznawczych); wskazana jest funkcjonalna ocena zachowania oraz zbieranie danych szczegółowych na temat ucznia/dziecka, wobec którego planujemy zastosować interwencję, tak by możliwa była najpełniejsza indywidualizacja treści i formy historyjki; 
2. Praca z historyjką społeczną:

a) dostosowanie treści:

zindywidualizowany zakres opowiadań społecznych - dobór treści dostosowany do poziomu rozwoju komunikowania się i mowy odbiorcy;

- dzielenie docelowej aktywności behawioralnej dziecka na mniejsze etapy;

powiązanie treści historyjek ze sobą;

- stopniowe rozszerzanie komunikatów werbalnych - zgodnie z zasadą „,krok po kroku”, z uwzględnieniem aktualnych możliwości językowych i poznawczych dziecka;

tworzenie historyjki, dbając o potrzeby, możliwości i zainteresowania dziecka jako wynik pracy zespołowej (nauczycieli, profesjonalistów, rodziców, opiekunów);

b) dostosowanie formy:

wykorzystanie w pracy z historyjką społeczną strategii wizualnych oraz technik wideo-modelowania;

- tworzenie materiałów w formie materialnej oraz w formie elektronicznej-e-booki, prezentacje, korzystając z aplikacji mobilnych, kreatorów, oprogramowania;

3. Monitorowanie postępów oraz ewaluacja pracy z historyjką społeczną:

- powracanie do historyjek społecznych w interwałach czasowych dostosowanych do potrzeb i możliwości odbiorcy;

- generalizowanie umiejętności (systematyczność, a nie długość trwania interwencji decyduje o możliwości prognozowania sukcesu jej zastosowania);

- dbanie o ciągłość oddziaływań w przedszkolu/ szkole oraz w domu poprzez psychoedukację oraz wsparcie rodziców dziecka w stosowaniu interwencji w środowisku domowym.

Dokonany przegląd raportów z badań opublikowanych w zagranicznych periodykach naukowych pozwolił na eksplorację możliwości wykorzystania interwencji w oparciu o historyjki społeczne w edukacji specjalnej. Mając na względzie obiektywne ograniczenia zaprezentowanych raportów, nasuwa się refleksja nad koniecznością kontynuowania badań nad skutecznością metody. Z perspektywy pedagogicznej istotne jest nie tylko opieranie się na metodach udowodnionych empirycznie (ang. evidence-based), na poziomie dociekań naukowych, ale także podejmowanie działań służących ich implementacji do codziennej praktyki szkolnej. 


\section{Bibliografia}

Adams L., Gouvousis A., VanLue M., Waldron C. (2004). Social story intervention: Improving communication skills in a child with an autism spectrum disorder, „Focus on Autism \& Other Developmental Disabilities”, 19(2), s. 87-94, DOI:10.1177/10883576040 190020301.

Agosta E., Graetz J.E., Mastropieri M.A., Scruggs T.E. (2004). Teacher-researcher partnerships to improve social behavior through social stories, „Intervention in School and Clinic”, 39, s. 276-287, DOI:10.1177/10534512040390050401.

Attwood T. (2013). Zespót Aspergera. Kompletny przewodnik, tłum. A. Sawicka-Chrapkowicz, Gdańsk: Harmonia Universalis.

Barry L.M., Burlew S.B. (2004). Using Social Stories to Teach Choice and Play Skills to Children With Autism, „Focus on Autism and Other Developmental Disabilities”, 19(1), s. 45-51, DOI:10.1177/10883576040190010601.

Beh-Pajooh A., Ahmadi A., Shokoohi-Yekta M., Asgary A. (2011). The effect of social stories on reduction of challenging behaviours in autistic children, „Procedia - Social and Behavioral Sciences”, 15 (2011), s. 351-355, DOI:10.1016/j.sbspro.2011.03.100.

Bernad-Ripoll S. (2007). Using a Self-as-Model Video Combined With Social StoriesTM to Help a Child With Asperger Syndrome Understand Emotions, „Focus on Autism and Other Developmental Disabilities”, 22(2), s. 100-106, DOI:10.1177/10883576070 220020101.

Chan J.M., O’Reilly M.F. (2008). A social stories intervention package for students with autism in inclusive classroom settings, "Journal of Applied Behavior Analysis”, 41(3), s. 405-409, DOI:10.1901/jaba.2008.41-405.

Chan M.J., O’Reilly M.F., Lang R.B., Boutot E.A., White P.J., Pierce N., Baker S. (2011). Evaluation of a Social Stories intervention implemented by pre-service teachers for students with autism in general education settings, „Research in Autism Spectrum Disorders”, 5, s. 715-721, https://doi.org/10.1016/j.rasd.2010.08.005.

Chrzanowska I. (2018). Pedagogika specjalna. Od tradycji do wspótczesności, Kraków: Oficyna Wydawnicza ,Impuls”.

Chrzanowska I. (2019). Nauczyciel o szansach i barierach edukacji wtaczającej, Warszawa: Wydawnictwo Naukowe PWN.

Cihak D.F., Kildare L.K., Smith C.C., McMahon D., Quinn-Brown L. (2012). Using Video Social Stories ${ }^{\mathrm{TM}}$ to Increase Task Engagement for Middle School Students With Autism Spectrum Disorders, „Behavior Modification”, 36(3), s. 399-425, DOI: $10.1177 / 0145445512442683$.

Crozier S., Tincani M. (2007). Effects of Social Stories on Prosocial Behavior of Preschool Children with Autism Spectrum Disorders. „Journal of Autism and Developmental Disorders", 37, s. 1803-1814, DOI:10.1007/s10803-006-0315-7.

Czakon W. (2011). Metodyka systematycznego przeglądu literatury, „Przegląd Organizacji”, nr 3, s. 57-61. 
Edeiken-Cooperman, N. (2014). The Use of Computer-Assisted Instruction as an Instructional Tool to Teach Social Stories to Individuals Who Have Been Diagnosed on the Autism Spectrum. SAGE Open.

Goldstein S., Ozonoff S. (2017). Perspektywa historyczna i ogólna charakterystyka, [w:] S. Goldstein, J.A. Naglieri, S. Ozonoff, Diagnoza zaburzeń ze spektrum autyzmu, tłum. R. Andruszko, Kraków: Wydawnictwo Uniwersytetu Jagiellońskiego.

Graetz J.E. (2003). Promoting Social Behaviors for Adolescents with Autism Using Social Stories, Doctoral Dissertation, the George Mason University, https://www.semanticscholar.org/paper/Decreasing-Inappropriate-Behaviors-for-Adolescents-Graetz-Mastropieri/a9b7a280e51 fee6af3c4c41b254500ad4787a3ed (dostęp: 09.03.2020).

Gray C. (2014). Nowe historyjki spoteczne. Ponad 150 historyjek, które uczq umiejętności spotecznych dzieci z autyzmem, zespotem Aspergera i ich rówieśników, Gdańsk: Wydawnictwo Harmonia.

Gray C.A., Garand J.D. (1993). Social Stories: Improving Responses of Students with Autism with Accurate Social Information, „Focus on Autistic Behavior”, 8 (1), s. 1-10, DOI:10.1177/108835769300800101.

Gray C. (1998). Social Stories and Comic Strip Conversations with Students with Asperger Syndrome and High-Functioning Autism, [w:] E. Schopler, G.B. Mesibov (red.), Asperger Syndrome Or High-Functioning Autism? Current Issues In Autism, Springer Science+Business Media, Llc, s. 167-198.

Hagiwara T., Smith M.B. (1999). A Multimedia Social Story Intervention: Teaching Skills to Children with Autism, "Focus on Autism and Other Developmental Disabilities”, 14(2), s. 82-95, DOI:10.1177/108835769901400203.

Hutchins T.L., Prelock P.A. (2012). Parents' Perceptions of Their Children's Social Behavior: The Social Validity of Social Stories ${ }^{\mathrm{TM}}$ and Comic Strip Conversations, "Journal of Positive Behavior Interventions”, 15(3), s. 156- 168, DOI:10.1177/1098300712457418.

Khantreejitranon A. (2018). Using a social story intervention to decrease inappropriate behavior of preschool children with autism, „Kasetsart Journal of Social Science”, 39, s. 90-97, DOI:10.1016/j.kjss.2017.12.019.

Kuoch H., Mirenda P. (2003). Social Story Interventions for Young Children With Autism Spectrum Disorders, „Focus on Autism and Other Developmental Disabilities”, 18(4), s. 219-227, DOI:10.1177/10883576030180040301.

Mancil G.R., Haydon T., Whitby P. (2009). Differentiated Effects of Paper and Computer-Assisted Social Stories ${ }^{\mathrm{TM}}$ on Inappropriate Behavior in Children With Autism, „Focus on Autism and Other Developmental Disabilities”, 24(4), s. 205-215, DOI:10.1177/1088357609347324.

Marr D., Mika H., Miraglia J., Roerig M., Sinnott R. (2007). The effect of sensory stories on targeted behaviors in preschool children with autism, „Physical and Occupational Therapy in Pediatrics”, 27, s. 63-79, DOI:10.1080/j006v27n01_05.

Mazur Z., Orłowska A. (2018). Jak zaplanować i przeprowadzić systematyczny przeglad literatury, „Polskie Forum Psychologiczne’, t. 23, nr 2, s. 235-251, DOI:10.14656/ PFP20180202. 
Morrison J. (2016). DSM-5 bez tajemnic. Praktyczny przewodnik dla klinicystów, Kraków: Wydawnictwo Uniwersytetu Jagiellońskiego.

National Autism Center (2015). Findings and conclusions: National standards project, phase 2, MA: Randolph.

Norris C., Dattilo J. (1999). Evaluating Effects of a Social Story Intervention on a Young Girl with Autism, „Focus on Autism and Other Developmental Disabilities”, 14(3), s. 180-186, DOI:10.1177/108835769901400307.

Pisula E. (2012). Autyzm. Przyczyny, symptomy, terapia, Gdańsk: Wydawnictwo Harmonia.

Prokopiak A. (2017). Uczeń z autyzmem, Lublin: Wydawnictwo Uniwersytetu Marii Curie-Skłodowskiej.

Pyszka A. (2015). Istota efektywności. Definicja i wymiary, „Studia Ekonomiczne. Zeszyty Naukowe", nr 230, s. 13-25.

Sansosti F.J. , Powell-Smith K.A. (2006). The effects of Social Stories on the social behavior of children with Asperger's Syndrome, „Journal of Positive Behavior Interventions”, 8 (1), s. 43-57, DOI:10.1177/10983007060080010601.

Scattone, D., Tingstrom D.H., Wilczynski S.M. (2006). Increasing Appropriate Social Interactions of Children With Autism Spectrum Disorders Using Social StoriesTM, „Focus on Autism and Other Developmental Disabilities”, 21(4), s. 211-222, DOI:10.1177/ 10883576060210040201.

Schneider N., Goldstein H. (2009). Social Stories ${ }^{\mathrm{TM}}$ Improve the On-Task Behavior of Children With Language Impairment, „Journal of Early Intervention”, Vol. 31(3), s. 250264, DOI:10.1177/1053815109339564.

Schneider N., Goldstein H., (2010). Using Social Stories and Visual Schedules to Improve Socially Appropriate Behaviors in Children With Autism, „Journal of Positive Behavior Interventions", Vol.12(3), s. 149-160, DOI:10.1177/1098300709334198.

Stathopoulou A., Loukeris D., Karabatzaki Z., Politi E., Salapata Y., Drigas A. (2020). Evaluation of Mobile Apps Effectiveness in Children with Autism Social Training via Digital Social Stories, „International Journal of Interactive Mobile Technologies”, Vol 14, No 03, s. 4-18, DOI:10.3991/ijim.v14i03.10281.

Suchowierska M., Novak G., (2013). Science and pseudoscience in the treatment of autism, „Postępy Nauk Medycznych”, t. XXVI, nr 1, s. 45-50.

Sunitha Balakrishnan S., Alias A. (2017). Usage of Social Stories in Encouraging Social Interaction of Children with Autism Spectrum Disorder, "Journal of ICSAR”, Vol.1(2), s. 91-97, DOI: 10.17977/um005v1i22017p091.

System Informacji Oświatowej, https:/cie.men.gov.pl/sio-strona-glowna/dane-statystyczne/niepelnosprawnosci-dane-statystyczne/ (dostęp: 03.03.2020).

Watts K. (2008). The Effectiveness of a Social Story Intervention in Decreasing Disruptive Behaviors in Autistic Children, Doctoral Dissertation, the Ohio State University, https:// www.google. $\operatorname{com} /$ url? sa =t\&rct=j\&q=\&esrc=s\&source=web\&cd=1\&ved=2ahUKEwir 9Y3d_6HoAhUyi8MKHTX9ACMQFjAAegQIAxAB\&url=https\%3A\%2F\%2Fetd. ohiolink.edu\%2F!etd.send_file\%3Faccession\%3Dosu1207928140\%26disposition\% 3Dattachment\&usg=AOvVaw1-yzldbahalu4NwNW7N8-K> (dostęp: 09.03.2020). 
Wright L.A., McCathren R.B. (2012). Utilizing Social Stories to Increase Prosocial Behavior and Reduce Problem Behavior in Young Children with Autism, "Child Development Research”, May, s. 1-13, DOI:10.1155/2012/357291

\section{ADRES DO KORESPONDENCJI}

\section{Dorota Pufund}

Uniwersytet Kazimierza Wielkiego w Bydgoszczy email: d.pufund@gmail.com 